\title{
Seasonal occurrence and local coexistence within scarabaeid dung beetle guilds (Coleoptera: Scarabaeoidea) in Tunisian pasture
}

\author{
FAÏEK ERROUISSI, IMEN LABIDI and SAÏD NOUIRA
}

UR: Biodiversité et Biologie des Populations, Institut Supérieur des Sciences Biologiques Appliquées de Tunis, 9 av. Zohaïr Es sefi, 1007 Tunis, Tunisie; e-mail: Faiek.Rouissi@issbat.rnu.tn, fickfack@yahoo.fr

Key words. Dung beetles, Northern Tunisia, guilds, phenology, coexistence

\begin{abstract}
Dung beetle assemblages were monitored using baited pitfall traps from January to December 2006 in Northern Tunisia. 4,965 beetles belonging to 37 species were trapped. Aphodius lineolatus and Onthophagus taurus dominated the assemblages. Results showed a significant seasonal variation in assemblage composition, and diversity. There were four periods of activity during the course of the year. Temporal turnover was highest in October and in February. Temporal distribution of species shows seasonal segregation and opposite patterns in the two dominant guilds (Aphodiinae-dwellers and Scarabaeidae-tunnelers). Aphodiidaedwellers were active from autumn to spring, although they were affected by summer drought. The Aphodius-dweller showed high temporal plasticity and phenological segregation. In contrast, Scarabaeidae-tunnelers were active all year round but mainly in the spring-summer period and less so in winter. Species in this guild showed a high degree of phenological overlap and a short ecological length. Our results suggest that coexistence in dung beetle guilds is facilitated by their phenological patterns, which reflect distinct ecological requirements and biogeographical origin of species. Geotrupidae-tunnelers and Scarabaeidae-rollers were rare and occurred mainly in the summer-autumn period, when individuals of the two other guilds were rare.
\end{abstract}

\section{INTRODUCTION}

The productivity of grazed ecosystems depends on the recycling of dung in which dung beetles play an important role. The activity of these insects is crucial to dung decomposition (Holter, 1982; Gitting et al., 1994) and they thereby enhance primary productivity (Fincher et al., 1981; Rougon \& Rougon, 1983). Studies in temperate and tropical areas (Rougon \& Rougon, 1980; Cambefort, 1982; Hanski \& Cambefort, 1991; Wassmer, 1994; Krell et al., 2003; Lobo et al., 2004) have demonstrated the role of scarabaeid dung beetles in the recycling of the animal excreta.

Scarabaeid dung beetles (Scarabaeoidea) belong to three distinct taxonomic groups: Scarabaeidae, Geotrupidae and Aphodiidae (Baraud, 1985).

The ephemeral character of their trophic resource affects the abundance of dung beetles but especially the possibilities of coexistence of many species in the same locality (Hanski, 1989). Most dung beetles are attracted to fresh herbivore and omnivore dung, and almost all Scarabaeidae and Geotrupidae species have developed complex nesting behaviour that enhance dung utilization and secures a food supply for their offspring (Cambefort \& Hanski, 1991).

Most of Aphodiidae species do not show nesting behaviour and oviposit in a mass of dung, where their larvae are exposed to competition and predation. Their lower sensitivity to soil characteristics and lower energy requirements permit Aphodiidae to be active where conditions are colder and competition is less, both at high latitudes (Hanski, 1991) and high altitudes (Lumaret \& Stiernet, 1991, Errouissi et al., 2004b; Jay-Robert et al., 2008b) where other groups are rare. Larval development in the dung pats obliges most Aphodiidae species to be active either when conditions are wet or cold, when diggers are less abundant.

In Northern Europe, communities of coprophagous beetles are dominated by Aphodiidae (Finn et al., 1999). Wassmer (1994) showed that the temporal dimension is an important factor structuring communities of dungbeetles in Central Europe. In the north Mediterranean regions, these communities are more diverse (Lumaret \& Kirk, 1987; Martin-Piera, 1992; Galante et al., 1995; Barbero et al., 1999). In these areas, species differ in their use of the trophic resources, which limits the degree of interspecific competition (Hanski, 1980; Holter, 1982; Hanski \& Cambefort, 1991).

Several studies describe the local dung beetle communities at temperate latitudes; in Northern Europe (Landin, 1961; Finn et al., 1999; Finn \& Guittings, 2003); Central Europe (Hanski, 1980; Holter, 1982; Wassmer, 1994); Southern Europe (Lumaret \& Kirk, 1987; Errouissi et al., 2004a, b; Zamora et al., 2007; Jay Robert et al., 2008a, b); Asia (Yasuda, 1984) and North America (Mohr, 1943).

Dung beetle communities are well-studied in the French Mediterranean area (Lumaret \& Kirk, 1987; Jay-Robert, 1997; Errouissi, 2003; Errouissi et al., 2004a, b Niogret, 2007; Jay-Robert et al., 2008a, b), Spain (Martin-Piera, 1992; Lumbreras Vicente, 1998; Sanchez Pinero \& Avila, 2004) and Morocco (Janati-Idrissi et al., 1999; JanatiIdrissi, 2000; Haloti et al., 2006), but until now not in Tunisia.

In the majority of the investigations, phenology proved to be one of the most important factors structuring dung 
beetle assemblages. Season was the most important factor determining niche separation in dung beetle guilds in temperate conditions (Sowig, 1997). Temporal separation of species can also be facilitated by the existence of several trophic guilds.

In this context, the purposes of the present paper were to: (i) study the seasonal pattern in the composition of Tunisian dung beetle assemblages in a sub-arid bioclimate; (ii) quantify the temporal distribution and local coexistence within and between the Tunisian guilds of dung beetles over a one year period and (iii) discuss and compare the local composition and structure and their temporal variation with that recorded in other studies from Mediterranean and temperate areas.

\section{MATERIAL AND METHODS}

\section{Study site}

Dung beetle assemblages were sampled from January to December 2006 in the Mejerda Valley, $15 \mathrm{~km}$ from Tunis (Tunisia; $36^{\circ} 52^{\prime} \mathrm{N}, 10^{\circ} 01^{\prime} \mathrm{E}$; altitude $38 \mathrm{~m}$ ). This area consists of an open landscape on clayey-sandy soils. The study site was cattle pasture of approximately 8 ha dominated by Medicago sativa (Nabli, 1995). This site is located in the sub-arid Mediterranean climate zone of Tunisia characterized by a cold winter; the annual mean temperature (for the last 5 years) of $18^{\circ} \mathrm{C}$, ranged between $27.1{ }^{\circ} \mathrm{C}$ (August) and $10.1{ }^{\circ} \mathrm{C}$ (January); and annual rainfall of $400 \mathrm{~mm}$, with November the wettest $(68.03$ $\mathrm{mm})$ and July the driest month $(0 \mathrm{~mm})$ (Fig. 1B).

\section{Sampling design}

Four baited pitfall traps situated $30 \mathrm{~m}$ apart, were used to collect the beetles. The pitfall design corresponds to the CeboSuspendido-Rejilla (CSR) model described by Lobo et al. (1988) and Veiga et al. (1989). Each trap consisted of a plastic basin $210 \mathrm{~mm}$ in diameter, buried to its rim in the soil and containing a water-formalin-liquid soap mixture. The fresh cow dung (1 l) used as the bait was supported on a wire grid above the basin. Dormont et al. (2004) and Errouissi et al. (2004a) showed that the use of cattle dung improves the efficiency of baited traps in Mediterranean climatic conditions (more water content). At both regional and local scales, Lobo et al. (1998) demonstrate that four pitfall traps sampled most of the species present at a site (between 60 and $70 \%$ species, which corresponds to a 89 and $93 \%$ abundance range, respectively). The trap contents were collected one week later and the dung renewed three weeks later for a further sampling period, which was repeated throughout the year.

\section{Data analysis}

All beetles were identified to species level and counted [nomenclature according to Baraud (1985) and Dellacasa et al. (2001), modified]. In May and November, only three traps were used (1 trap accidentally destroyed), so average number of individuals per trap was used for statistical analysis.

To compare assemblages, the monthly variation was described by parameters that include species richness, monthly changes in assemblages, composition and diversity. The species diversity was estimated using the $H^{\prime}$ Shannon index:

$$
H^{\prime}=-p_{i} \Sigma \log _{2} p_{i}
$$

where $p_{i}$ is the proportion of the $i$-species to the total number of species in each monthly sample.

The beta-diversity index of Whittaker expresses the change in the fauna (turnover) over time, i.e., between monthly assemblages (temporal scale):

$$
\beta w=(\mathrm{S} / \alpha)-1
$$

where $S$ is the total number of species in assemblages and $\alpha$ the average number of species observed within assemblages. $\beta w$ varies between 0 (identical species composition) and 1 .

The evenness or equitability E was calculated as below:

$$
E=H^{\prime} / \log _{2} N
$$

where $N$ is the number of species.

Species abundance (average per trap) was $\log (x+1)$ transformed and a cluster analysis based on Bray-Curtis coefficient performed to determine the similarity between months and the season when coprophagous beetles are active. Statistical differences between seasons were tested using one-way ANOSIM.

The numbers of individuals (average per trap) were $\log (x+1)$ transformed and used in correspondence analysis (CA) to determine the variation in the composition of assemblages, differences between months and the temporal distribution of species. $\mathrm{CA}$ and derived statistics allowed us to characterize the temporal activity of adult beetles and analyse co-occurrence patterns. The distribution of species among ecological guilds [Aphodiidae-dwellers (Ad), Geotrupidae-tunnelers (Gt), Scarabaeidae-tunnelers (St), and Scarabaeidae-rollers $(\mathrm{Sr})]$ was then used to characterize the temporal activity of each group.

Derived statistics were obtained from the CA analysis. The mean score of each ecological guild was calculated as follow, taking into account the first two axes $1-2$ of CA:

$$
X=\Sigma\left(n_{i} * x_{i}\right) / n
$$

with $n_{i}=$ abundance of species $i ; x_{i}=$ score of the species $\mathrm{i}$ on the corresponding axis; $n=$ total abundance of species belonging to the same ecological guild.

The standard deviation of the scores for each ecological guild (Ad, St, Sr and Gt) along axes 1 and 2, respectively, was:

$$
S D=\sqrt{\sum n_{i} *\left(x_{i}-X\right)^{2} / n}
$$

with $n_{i}=$ abundance of the species $i ; n=$ total abundance of species belonging to the same ecological guild; $x i=$ score of the species $i$ on the corresponding axis; $X=$ mean score of the ecological guild (see previous equation 4). The standard deviation is an estimate of the ecological tolerance of each ecological guild (Chessel et al., 1982).

The standard error of the scores for each species along axes 1 and 2, respectively, was computed as follow:

$$
S E=\sqrt{\sum n_{i} *\left(x_{i}-x\right)^{2} / n}
$$

with $n_{i}=$ abundance of the species in the sample $\mathrm{i} ; n=$ total abundance of the species; $x_{i}=$ coordinate of the sample i; $x=$ coordinate of the species. The standard error was an estimate of the ecological range occupied by the species (Chessel et al., 1982).

Along axes 1 and 2, respectively, the distances between species in the same ecological guild and between species belonging to different guilds were estimates of the ecological differences between species and calculated using the Euclidean distance. Non-parametric Mann-Whitney tests were used for all pairwise comparisons of distances between species intra and inter-guilds, standard error of species. The Spearman rank correlation $\left(r_{s}\right)$ test was used to study eventual correlation. All statistical analyses were performed with Statistica 6 and Past software.

\section{RESULTS}

\section{Species composition of assemblage}

The pooled sample for the trapping period (JanuaryDecember 2006) included 4,965 beetles belonging to 37 

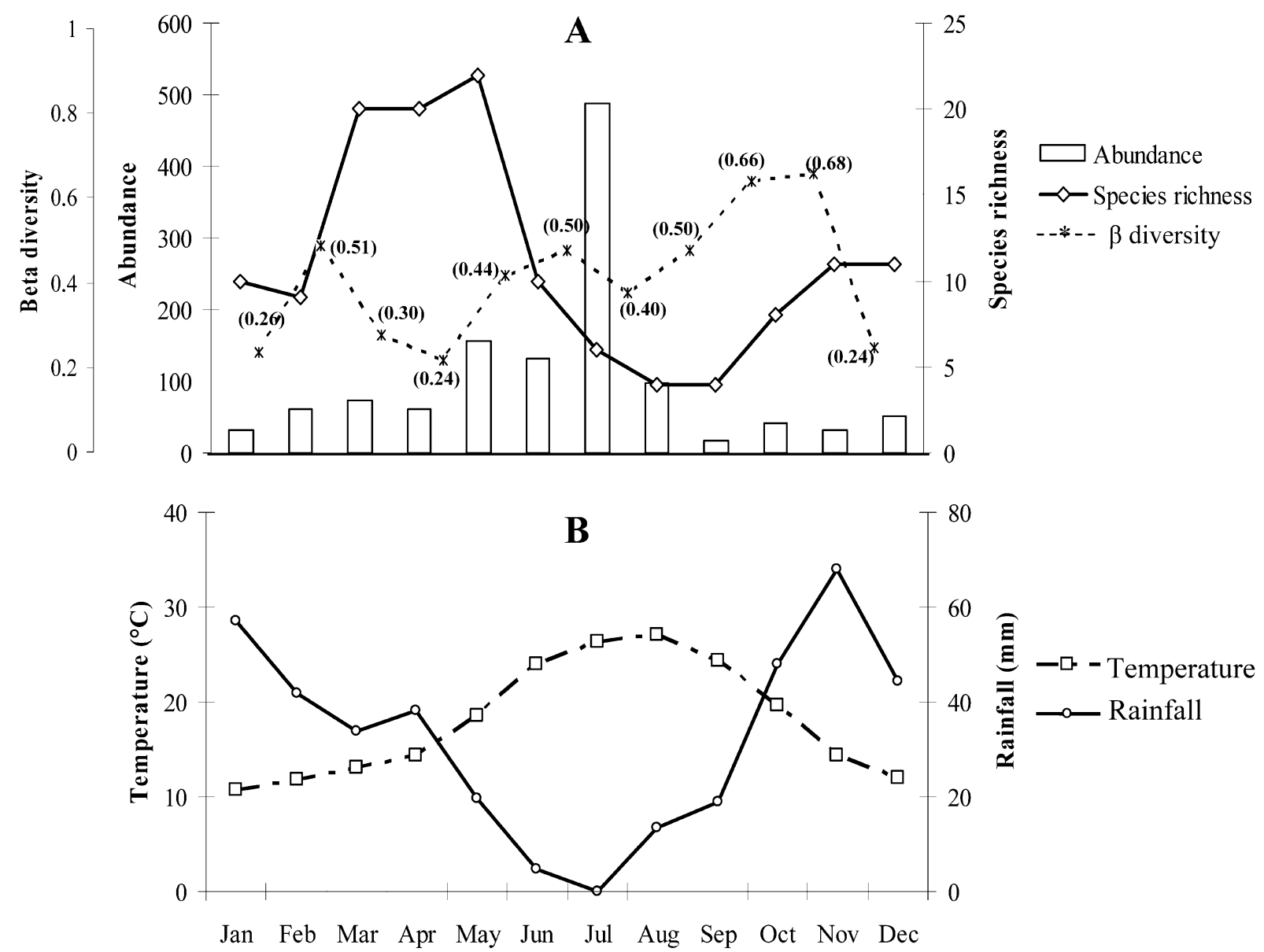

Fig. 1. A: Temporal variation in abundance, species richness and beta diversity of dung beetles trapped during the course of a year. In brackets: beta diversity value between two successive months. B: Mean monthly temperature $\left({ }^{\circ} \mathrm{C}\right)$ and rainfall $(\mathrm{mm})$.

species: 19 Aphodiidae-dwellers (52.63\%), 14 Scarabaeidae-tunnelers (36.84\%), one Scarabaeidae-roller (2.63\%) and three Geotrupidae-tunnelers (7.89\%) (Table 1).

Aphodiidae-dwellers were active throughout most of the year, except during the driest period (June to September), with two exceptions, Colobopterus erraticus was active in June and Anomius castaneus in September. Scarabaeidae-tunnelers showed a major peak of activity of species and individuals in spring-summer (May to August). The Geotrupidae-tunnelers activity showed two peaks, a high one in spring and a low one in autumn. Finally, the only Scarabaeidae-roller (Gymnopleurus sturmi) was trapped sporadically but more so in June, July, September and December.

There was a negative correlation between rainfall and number of species of all the four ecological guilds $\left(r_{s}=\right.$ $-0.71 ; P=0.009)$. Species richness showed positive correlation with temperature $\left(r_{s}=0.56 ; P=0.054\right)$.

The lowest values of the diversity ( $\left.\mathrm{H}^{\prime}\right)$ and evenness (E) indices were obtained during July-September, due to the absence of Ad and Gt and the abundance of Onthophagus taurus, which dominated the dung beetle assemblages.

The highest beta-diversity values were found between September and October, and October and November (0.66 and 0.68 , respectively) (Fig. 1A). The same pattern was observed from February to March (0.51) and June to July $(0.50)$. This indicates that there was considerable seasonal constancy in the species composition.

\section{Seasonality and temporal coexistence}

The seasonal changes in abundance of the most abundant species (more than 10 ind. $\operatorname{trap}^{-1}$ year $^{-1}$ ) are presented in Fig. 2A as relative frequency distributions. Most of the species were univoltine, exceptions being Calamosternus granarius and Bubas bison, with two periods of occurrence (spring and autumn), and Onthophagus taurus, active from April till November.

Several temporal patterns in beetle activity were apparent: unimodal with species active from late autumn to late spring (Alocoderus hydrochaeris, Melinopterus tingens, Chilothorax lineolatus), unimodal species active from spring to early summer (Colobopterus erraticus, $O$. nigel$l u s)$; unimodal with species active from early spring till autumn (Euoniticellus fulvus, E. pallens), unimodal with species showing autumnal activity (Erytus pruinosus) and bimodal species (Calamosternus granarius, Bubas bison, Onthophagus taurus). As mentioned above, the six most abundant species of Aphodiidae showed a far more noticeable temporal segregation than did the five most abundant species of Scarabaeidae species (Fig. 3a, b), which overlapped temporally. 


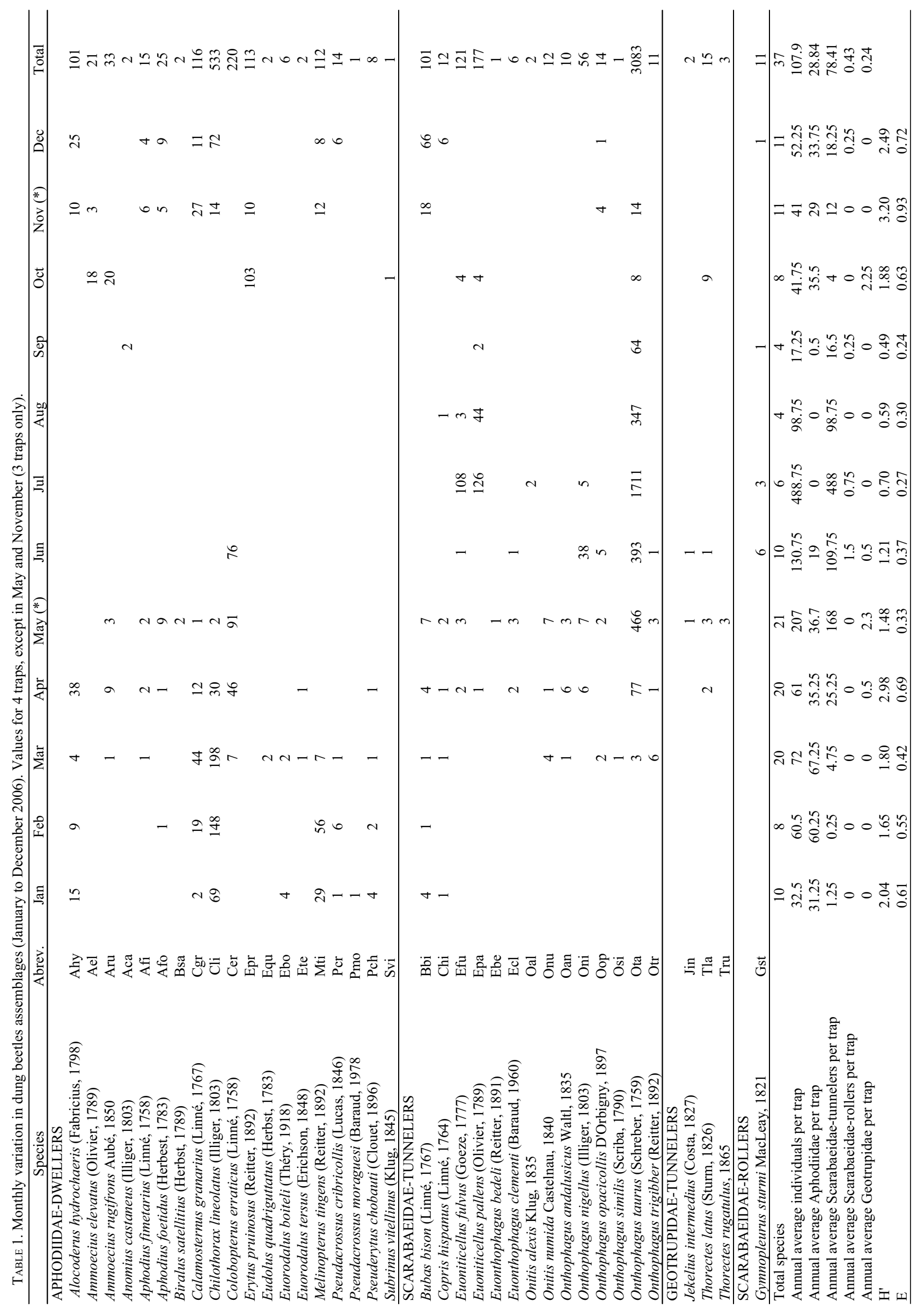


Aphodiidae-dwellers

Alocoderus hydrochaeris

(25.25)

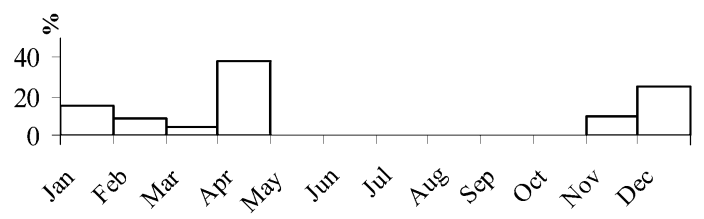

Calamosternus granarüs

(29)

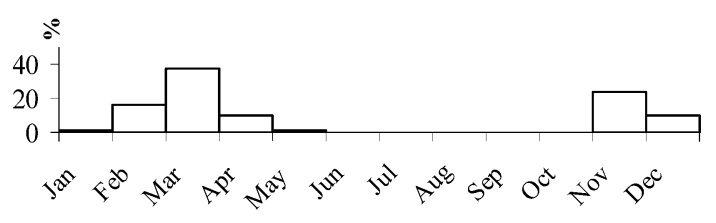

Colobopterus erraticus

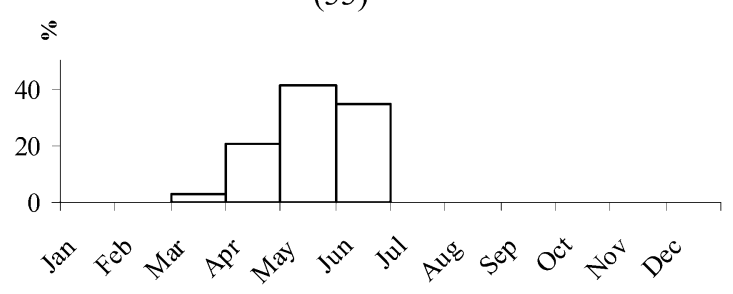

Erytus pruinosus (28.5)

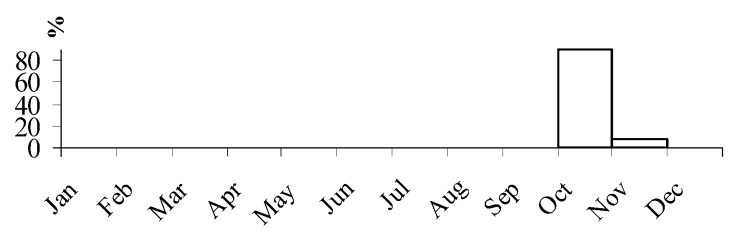

Melinopterus tingens

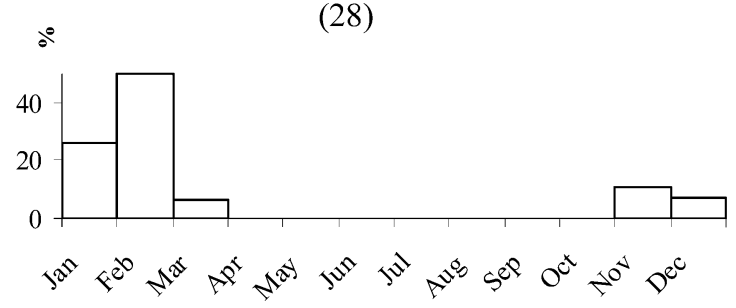

Chilothorax lineolatus

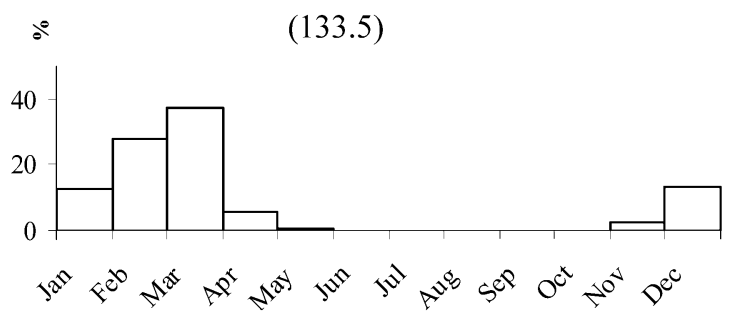

Scarabaeidae-tunnelers

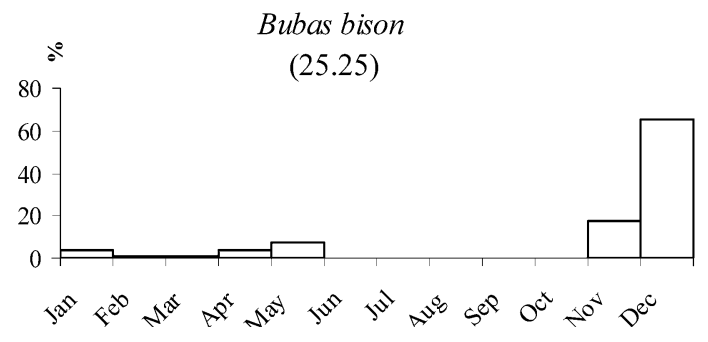

Euoniticellus fulvus (30.25)

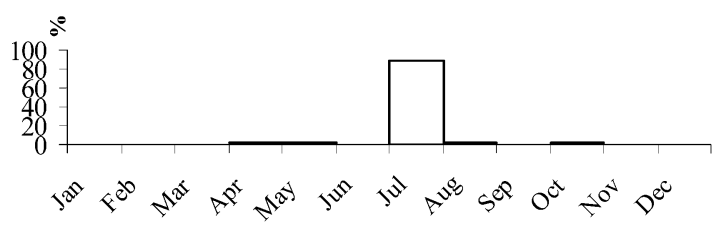

Euoniticellus pallens

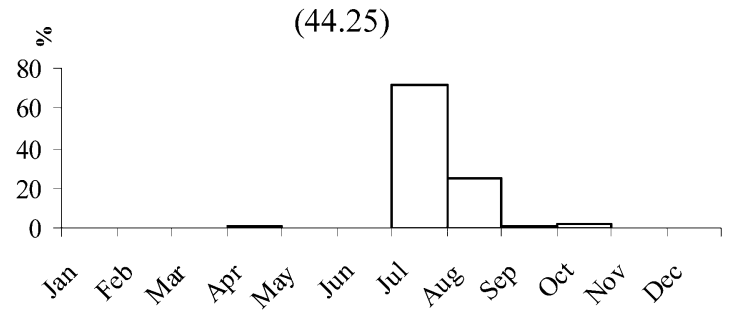

Onthophagus nigellus

(14)

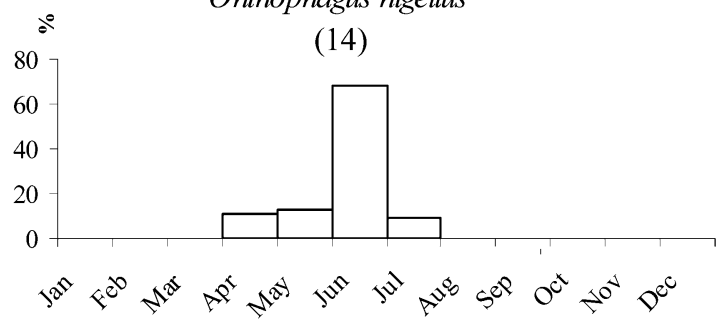

Onthophagus taurus (770.75)

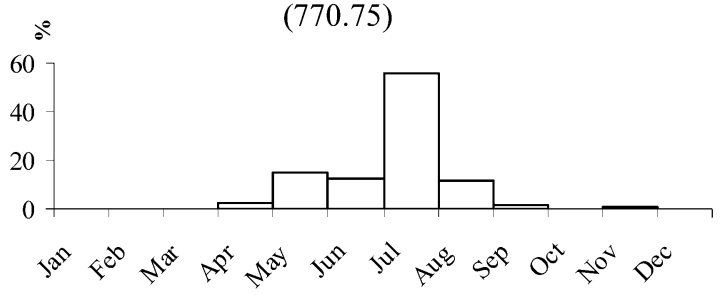

Fig. 2. Seasonal occurrence of the 11 most abundant scarabeid species ( $>10$ ind./trap/year). Ordinate: relative percentages (\%) based on mean abundance. Below each species (in brackets): total no. of individuals. See Table 1 for species abbreviations.

89 

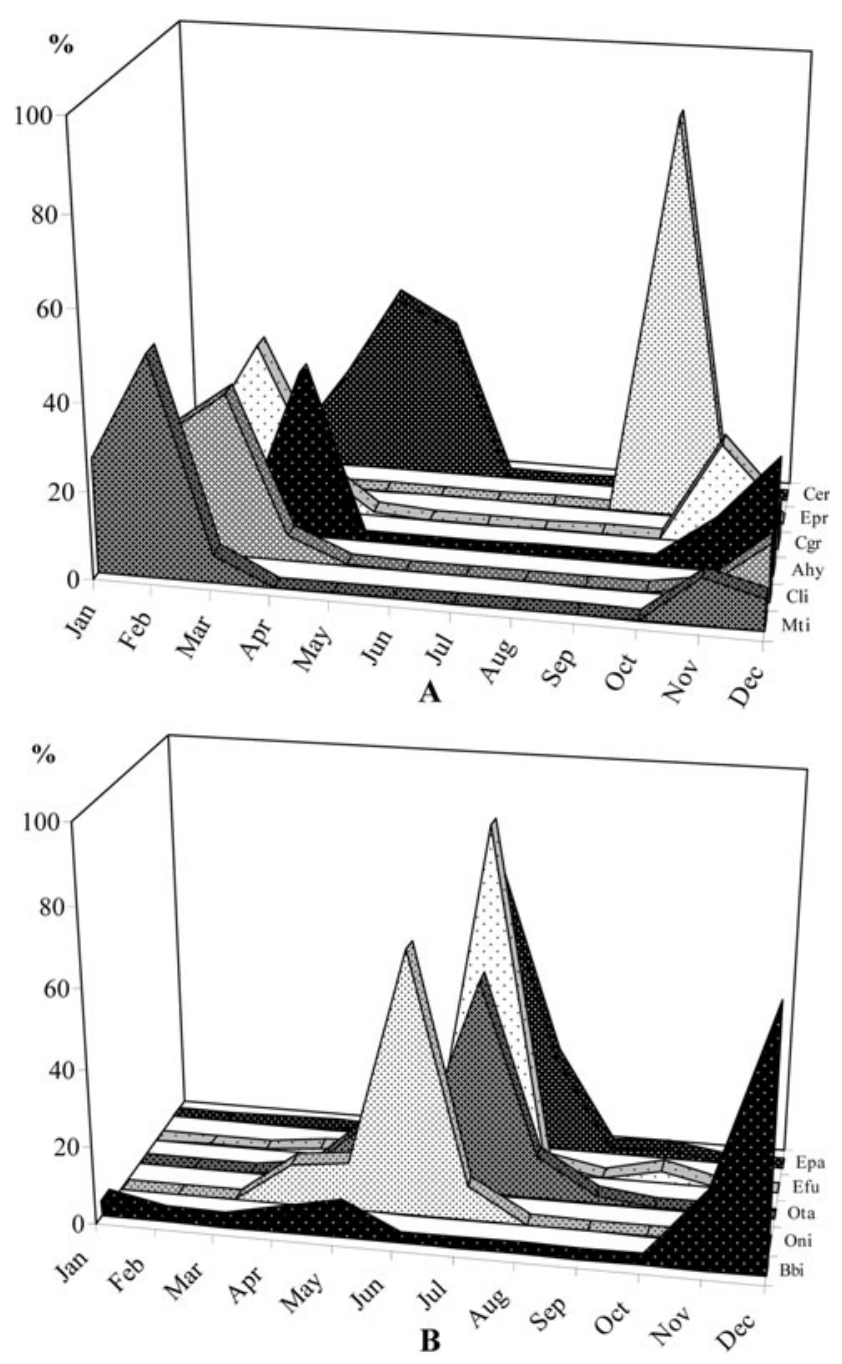

Fig. 3. Seasonal segregation of species of Aphodiidaedwellers (A) and Scarabaeidae-tunnelers (B). X-ordinate: time (month); Y-ordinate: abundant species (no. > 10/trap/year); Z-ordinate: relative percentage (\%) based on mean abundance. For abbreviations of species names see Table 1 .

Cluster analysis identified four periods of dung beetles abundance (Fig. 4): (i) autumn-winter period (November till March) characterized by dominance of Ad; (ii) spring period (April till June), with a similar diversity and abundance of Ad and St; (iii) summer period (July till September) with no Ad and Gt and a dominance of St; (iv) October marked by the return of Ad and a few other species and the disappearance of St and $\mathrm{Sr}$.

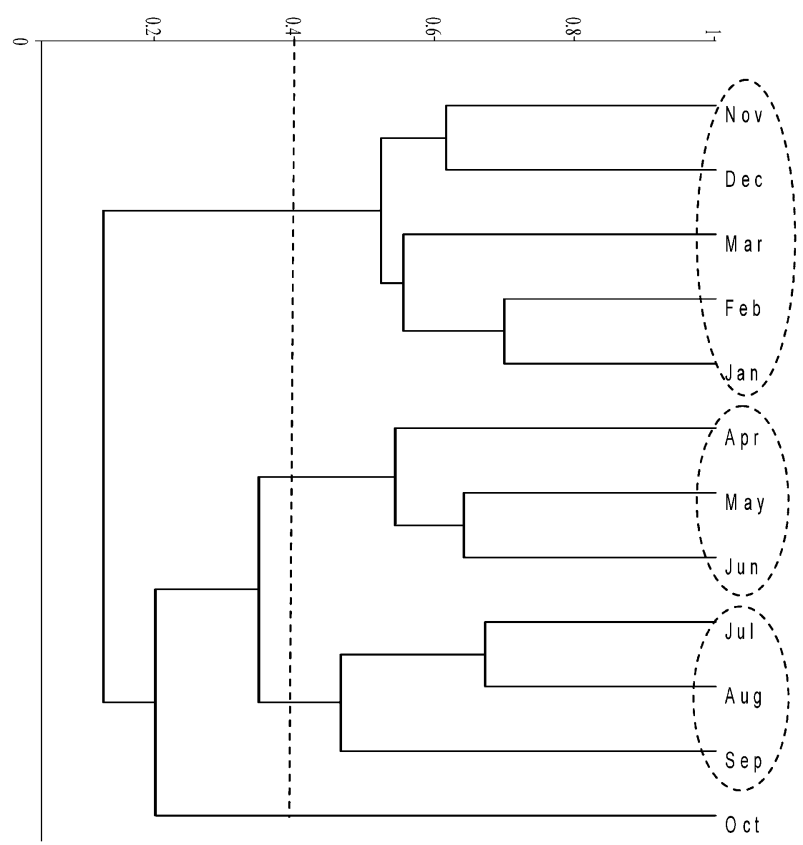

Fig. 4. Similarity of the monthly abundance of species based on the Bray-Curtis index, indicates four distinct clusters: (i) November-March; (ii) April-June; (iii) July-September and (iv) October.

CA revealed a strong influence of time (Fig. 5). The main gradient in the ordination, running approximately from right to left, clearly discriminated Ad species from species belonging to the three other functional guilds (St, $\mathrm{Sr}, \mathrm{Gt})$. Species were temporally distributed along axis1 account for $31.2 \%$ of total variance. Axis 2, which gathered $21.6 \%$ of total variance, discriminates species according to their ecological requirements and/or biogeographical origins. It separates St and $\mathrm{Sr}$ from Ad and Gt.

Aphodiidae-dwellers (Ad) were active almost all year round (from October to June, quasi but absent in July-August) and distributed all along axis 1 of the CA. Consequently, species of this guild had a higher range of activity (assessed by the SD of the guild) than other beetles (Table 2). The species turnover was maximal from June to November (0.66 to 1) (Fig. 6).

Scarabaeidae-tunnelers (St) were active all the year, with a peak in activity in spring-summer. The maximum specific richness was observed in April-May and the minimum from September to February. Along CA axis 1, this guild had an opposite mean score compared to Ad. Scarabaeidae-tunnelers had a smaller SD than Ad. The

TABLE 2. Position and scattering of the four ecological guilds: Aphodiidae-dwellers, Scarabaeidae-tunnelers, Scarabaeidae-rollers and Geotrupidae-tunnelers on the plane (1-2) of the CA.

\begin{tabular}{|c|c|c|c|c|c|c|}
\hline \multirow{2}{*}{ Guilds } & \multicolumn{2}{|c|}{ Mean score (guilds) } & \multicolumn{2}{|c|}{ Standard deviation (guilds) } & \multicolumn{2}{|c|}{ Standard error (species) } \\
\hline & Axis1 & Axis2 & Axis1 & Axis2 & Axis1 & Axis2 \\
\hline Aphodiidae-dwellers & -0.54 & -0.18 & 0.62 & 0.84 & $0.32( \pm 0.13)$ & $0.30( \pm 0.36)$ \\
\hline Scarabaeidae-tunnelers & 0.82 & 0.34 & 0.32 & 0.08 & $0.35( \pm 0.19)$ & $0.21( \pm 0.15)$ \\
\hline Scarabaeidae-rollers & 0.87 & 0.69 & 0.00 & 0.00 & $0.20( \pm 0.0)$ & $0.54( \pm 0.0)$ \\
\hline Geotrupidae-tunnelers & 0.60 & -1.03 & 0.08 & 0.83 & $0.59( \pm 0.12)$ & $0.25( \pm 0.34)$ \\
\hline
\end{tabular}




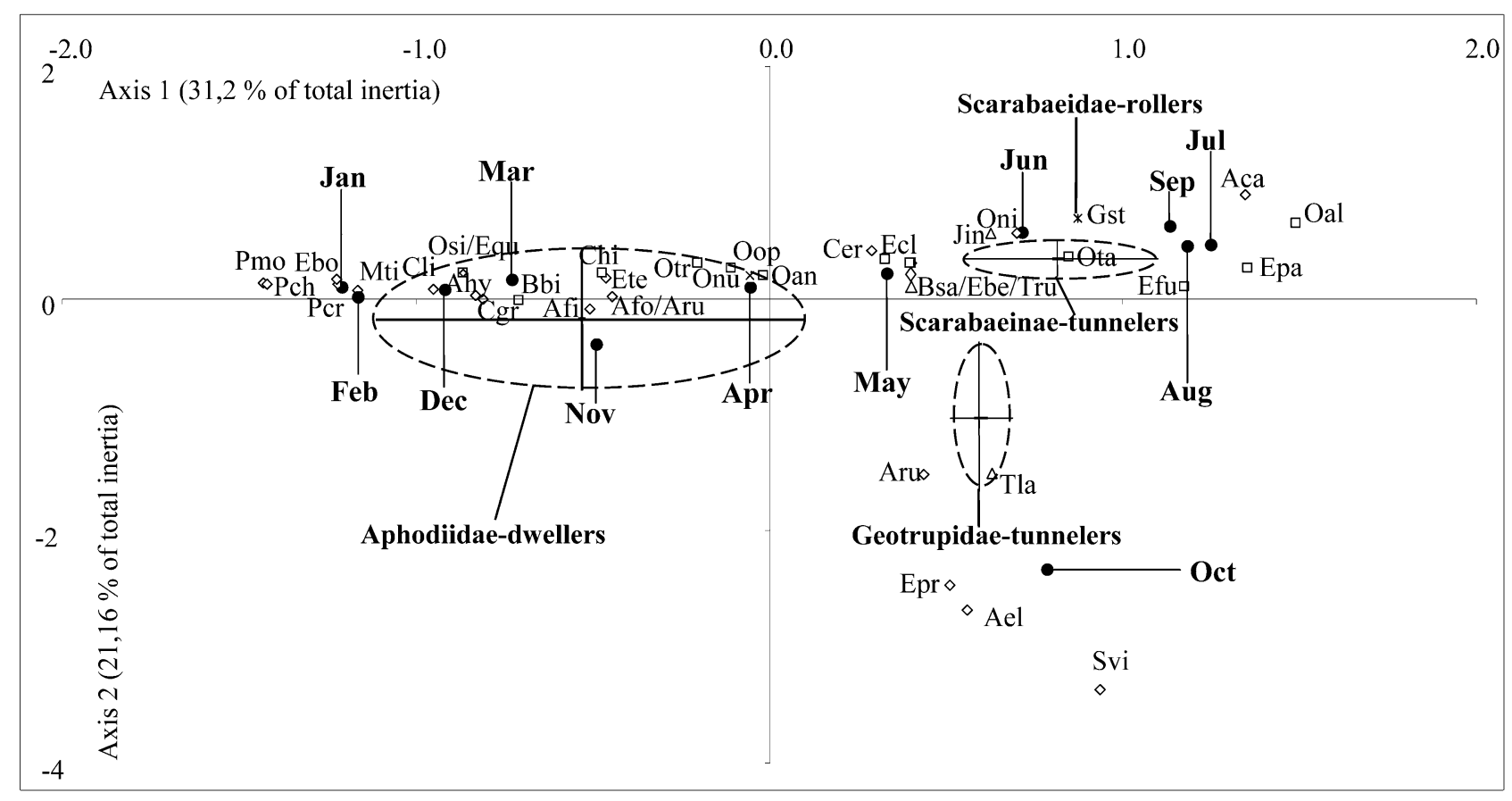

Fig. 5. Plot of species sampled at the study site in different months, on the two axes of a CA. For each guild (Aphodiidae-dwellers $\diamond$, Scarabaeidae-tunnelers $\square$, Scarabaeidae-rollers $\times$ and Geotrupidae-tunnelers $\Delta$ ) the barycentre and the standard deviation along axes are represented by an ellipse (the barycentre is the centre of the ellipse, the standard deviation for axis 1 is the axis of the ellipse that is parallel to axis 1, the SD for axis 2 is the axis of the ellipse parallel to axis 2). See table1 for the species names of the abbreviations.

species turnover was maximal from February to March $(\beta w=0.77)$ and October to November $(\beta w=0.66)($ Fig. 6).

On the $[1 ; 2]$ plane of the $\mathrm{CA}$, the mean distances within guilds Ad and St were 1.3 and 1.53, respectively. These values were significantly higher than for Gt (Dist ${ }_{\mathrm{Gt}}$ $=0.43 ; \mathrm{U}=90, P=0.042$ and $\mathrm{U}=26 ; P=0.002$, respectively). No significant difference was observed between Ad and St $(\mathrm{U}=8608.5 ; P=0.95)$. It was not possible to compare the $\mathrm{Sr}$ guild with the Ad and St guilds. When related (within guild) and unrelated (inter-guilds) species were compared, there was a significant difference between Ad and Gt $(\mathrm{U}=4269.5 ; P=0.003)$ and $\mathrm{St}$ and Gt $(\mathrm{U}=1411 ; P=0.002)$ (Table 3$)$.

There were no significant differences in the standard errors (SE) along axis 1 and 2 of the CA, nor between Ad and $\mathrm{St}$ and other guilds.

Geotrupidae-tunnelers (Gt) were represented by three species from April to May and in October. Gt had a smaller SD along axis 1 and greater SD along axis 2. On the plane $[1 ; 2]$ of the $\mathrm{CA}$, the mean distance within guild was 0.43 , which is significantly lower than that for the Ad and St guilds. It was not possible to compare them with $\mathrm{Sr}$ (one species). For Gt, the distances between related and unrelated species were not statistically different along axis 1 and 2. Similarly, there were no differences in the standard errors of the values (SE) for Gt and the other guilds.

Scarabaeidae-rollers $(\mathrm{Sr})$ were only represented by the scarce Gymnopleurus sturmi $(<2$ individuals per trap in June, July, September and December). As there were few individuals of only a few species further statistical analyses of this guild was not possible.

\section{DISCUSSION AND CONCLUSION}

Using this trapping method we collected 38 species over a period of one year, which is approximately $30 \%$ of the total fauna of Tunisia (Baraud, 1985). In Morocco, Janati et al. (1999) trapped between 24 and 41 species at 6 sites (an average of 36.3 species per site). Haloti et al. (2006) collected between 32 and 40 species (37 on average) at five Moroccan sites. In South of France, Jay-

TABLE 3. Distance between species within guilds and between species belonging to different guilds on plane (1-2) of the CA. Euclidean distance was used.

\begin{tabular}{lcccc}
\hline \multicolumn{1}{c}{ Guilds } & Aphodiidae-dwellers & Scarabaeidae-tunnelers & Scarabaeidae-rollers & Geotrupidae-tunnelers \\
\hline Aphodiidae-dwellers & $1.30( \pm 0.85)$ & & & \\
Scarabaeidae-tunnelers & $1.45( \pm 1.18)$ & $1.53( \pm 1.34)$ & 1.06 & $0.43( \pm 0.22)$ \\
Scarabaeidae-rollers & $1.06( \pm 0.73)$ & $1.08( \pm 1.07)$ & $0.56( \pm 0.15)$ & $0.05( \pm 1.15)$ \\
Geotrupidae-tunnelers & $0.94( \pm 0.78)$ & $1.05)$ \\
\hline
\end{tabular}



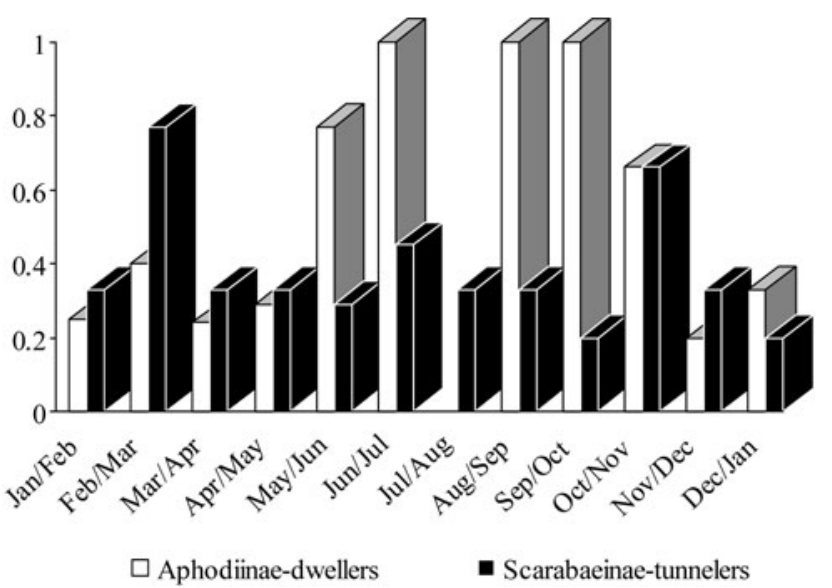

Fig. 6. Temporal variation of the beta-diversity (turnover) for the two dominant guilds (Aphodiinae-dwellers and Scarabaeinae-tunnelers) at the study site.

Robert et al. (2008a) collected 46 species at a low altitude $(250 \mathrm{~m})$ and 43 species at a medium altitude $(800 \mathrm{~m})$. In the Alps, 48 species were collected at five sites using similar pitfall traps (Errouissi et al., 2004b) and 40 species in the Northern Alps (Lumaret \& Stiernet, 1991). Thus, the number of species we captured at one site is of the same order of magnitude as that recorded in the literature.

Seasonality in insects is mainly associated with three factors: resource availability, temperature and rainfall (Wolda, 1988). During hot and dry periods, dung quickly becomes unsuitable for most beetles (Rougon \& Rougon, 1983; Hanski \& Cambefort, 1991). Hence resource availability for these beetles may vary with temperature and rainfall. Two factors are critical for many dung beetles in sub-Mediterranean areas: winter is quite cold and the middle of summer very dry, which results in a concentration in the activity of dung beetles in spring and autumn (Lumaret \& Kirk, 1987). Our results confirm these findings, but in Tunisian pastures dung beetles were active throughout the year, although the abundance of the species was negatively correlated with rainfall and species richness positively correlated with temperature. In the area of the French Mediterranean, most species are inactive in summer and absent in winter, except for those that have adopted an exceptional phenology, ovipositing during the coldest winter period (e.g. Agrilinus constans) or the driest period (e.g. Ammoecius elevatus), which allows them to avoid competition with most other species (Lumaret \& Kirk, 1987).

The cluster analysis makes it possible to identify four periods of activity of Tunisian dung beetles (see Fig. 4). When compared with the French Mediterranean fauna (Errouissi, 2003), the biological seasons identified were: (i) autumn (September-October); (ii) winter (November till February); (iii) spring (March till June) and (iv) summer (July-August).

Results from beta-diversity analysis confirm this seasonality in dung beetle assemblages, with the highest values between summer and October, and between October and the autumn-winter period. The main tem- poral turnover occurs between September and October in central and northern Europe (Wassmer, 1994; Finn et al., 1999). In Tunisia, Aphodiinae-dwellers (Ad) showed a temporal constancy from November to May, and St from March till October. Considering the short temporal scale in tropical landscapes, high turnover (high beta-diversity) is characteristic of non stable habitats or a consequence of insufficient sampling (Moreno \& Halffter, 2001). In Mediterranean ecosystems, high beta-diversity (high temporal heterogeneity) could be due to temporal variability in species composition of assemblages and may be the result of a well established community adapted to temporally changing Mediterranean conditions (drastic seasonality) (Zamora et al., 2007).

In our study most species were univoltine and those that were bivoltine under French Mediterranean conditions, e.g. Bubas bison and Calamosternus granaries, were present over a longer period of time but without distinguishable peaks. The lack of bimodality in these species is probably attributable to overlapping generations. Lumaret \& Kirk (1987) record two activity peaks for most species under Mediterranean conditions, a major one at the end of spring (oviposition period) and a second smaller one in autumn, much reduced, which coincides with the first heavy autumnal rain.

Aphodiidae species in the current study made up more than $52 \%$ of all the dung beetles (in numbers) trapped. Species of this guild are normally absent during the summer period when the rapid desiccation of droppings prevents breeding by most dung dwellers (Lumaret, 1995). Only one species was active in September (Anomius castanius). In contrast, winter in Tunisia is a favourable period for many dweller species (9 to 11 Aphodiidae species). Related species of Aphodiidaedwellers showed the highest phenological segregation (estimates based on SD). Such segregation in is also recorded in the French Mediterranean area (Jay-Robert et al., 2008a), the Alps (Jay-Robert et al., 2008b) and central Europe (Wassmer, 1994). This suggests phenological diversity within Aphodiidae facilitates the co-existence of many sympatric species. SD of this guild was larger, which suggests a long period of activity and greater level of temporal segregation between species. This temporal plasticity could enhance the local diversity and allow the coexistence of related species (Hanski, 1991).

Scarabaeidae-tunnelers (St) made up $\approx 37 \%$ of total species captured in this study. Several species were active throughout the year and during summer, with Onthophagus taurus dominant. This species is also reported to dominate dung beetle assemblages in Morocco (Haloti et al., 2006). Winter was a more unfavourable period for species of this guild. The SD values suggest less temporal plasticity in this guild, which results in fewer local species, and an increase in competition between the species. Indeed a shortening of the activity period of St species (estimated using species SE) was recorded. Adult St were mostly active in spring-summer and there was a marked phenological overlap between species. Similar results are recorded for the French Mediterranean area for St (Jay- 
Robert et al., 2008a). Such a high degree of temporal coexistence suggests competition between species in this guild is not important. In central Europe (Wassmer, 1994) and France (Errouissi, 2003; Jay-Robert et al., 2008a) these tunnelers had similar phenologies.

On plane [1-2] of CA, St occupies a position opposite that of Ad. The monthly abundance of the two guilds was negatively correlated $(\mathrm{r}$-spearman $=-0.67 ; \mathrm{P}=0.017)$. The two guilds were highly diverse in March-May and St continued to be active in summer, but was scarce in winter, with the opposite pattern for the Ad species, which facilitates the coexistence of the two guilds. The projection on plane $[1,2]$ of the CA of the two clusters was significantly different $(\mathrm{U}=84 ; \mathrm{P}=0.050)$. This could imply that the seasonal occurrence of the species at the same site depends on the phylogenetic relation between species within each guild and coevolution of the guilds.

Scarabaeidae-tunnelers are mostly active during springsummer and are well adapted to the warm conditions that predominate in Africa and in the Mediterranean area (Lobo et al., 2002, Errouissi et al., 2004b, Jay-Robert et al., 2008a, b). Conversely, most Ad are well adapted to mild and wet periods of the year, or even to cold periods (northern Europe; mountains up to the snow line), which probably correspond to distinct ecophysiological requirements (Jay-Robert et al., 1997).

Scarabaeidae-rollers and Geotupinae-tunnelers showed distinct patterns and were never active all year round. Geotupinae-tunnelers were mainly active in autumn, when most species reproduce (Lumaret \& Kirk, 1987; Errouissi, 2003; Errouissi et al., 2004b; Jay-Robert et al., $2008 \mathrm{a}, \mathrm{b})$. In our study Gt were represented by three wingless species belonging to the genus Thorectes, which were more abundant in spring than autumn. In spite of their low abundance and occurrence, these species had a long adult activity period (estimated using SE).

The only Scarabaeidae-roller captured (Gymnopleurus sturmi) was active in late spring, summer and December, with a maximum in June. In Morocco, this species dominates spring dung beetle assemblages in sub-arid climatic conditions (Janati-Idrissi et al., 1999). Similar results are recorded by Haloti et al. (2006) for Morocco.

Our results make it possible to conclude that the coexistence of dung beetles in ephemeral and patchy habitats in a variable environment can be explained partly by differences in species life-history traits and separation in time. The seasonal changes in activity of the guilds can be interpreted as the result of a long-term co evolution of species resulting in a widening of niches, which reduces competition. The seasonal distribution of species may result from a relatively constant level of trophic resource during the year. Local coexistence and differences in phenology in dung beetles communities may reflect past competitive interaction, as mentioned by Hanski (1980).

The coexistence of species is based on a complex seasonal segregation within and between guilds. If $\mathrm{St}$ and $\mathrm{Sr}$ together monopolize most of the resource (due to their numbers and size), Ad species have to be active in other periods of the year when competition is less severe as strong and Scarabaeidae are scarce (Hanski \& Cambefort, 1991; Krell-Westerwalbesloh et al., 2004).

ACKNOWLEDGEMENTS. We would like to thank J.-P. Lumaret (UMR 5175, Montpellier) for his helpful comments and suggestions on an early and a latter version of the manuscript, and P. Bordat for his comments and help with species nomenclature. We thank also O. Jendoubi who provided cattle and pasture. Finally, the helpful criticism of the manuscript by the three anonymous reviewers and the editor is gratefully acknowledged.

\section{REFERENCES}

Baraud J. 1985: Coléoptères Scarabaeoidea. Faune du Nord de l'Afrique du Maroc au Sinaï. Lechevalier, Paris, 651 pp.

Barbero E., Palestrini C. \& Rolando A. 1999: Dung beetle conservation: effects of habitat and resource selection (Coleoptera: Scarabaeoidea). J. Insect Conserv. 3: 75-84.

CAmbefort Y. 1982: Les Coléoptères Scarabaeidae s. str. de Lamto (Côte d'Ivoire): structure des peuplements et rôle dans l'écosystème. Ann. Soc. Entomol. Fr. (N.S.) 18: 433-459.

CAmbefort Y. \& Hanski I. 1991: Dung beetle population biology. In Hanski I. \& Cambefort Y. (eds): Dung Beetle Ecology. Princeton University Press, Princeton, NJ, pp. 36-50.

Chessel D., Lebreton J.D. \& Prodon R. 1982: Mesures symétriques d'amplitude d'habitat et de diversité intra-échantillon dans un tableau espèce-relevé: cas d'un gradient simple. $C$. $R$. Acad. Sci. Paris III (Sci. Vie) 295: 83-88.

Dellacasa G., Bordat P. \& Dellacasa M. 2001: A revisional essay of world genus-group taxa of Aphodiidae. Mém. Soc. Entomol. Ital. 79: 1-482.

Dormont L., Epinat G. \& Lumaret J.P. 2004: Trophic preferences mediated by olfactory cues in dung beetles colonizing cattle and horse dung. Environ. Entomol. 33: 370-377.

Errouissi F. 2003: Effet des Anthelminthiques sur les Insectes Coprophages. Conséquences Environnementales. Thèse doct. Biologie des Populations et Ecologie, Univ. Montpellier III, France.

Errouissi F., Haloti S., Jay-Robert P., Janati-Idrissi A. \& LUMARET J.P. 2004a: Effects of the attractiveness for dung beetles of dung pat origin and size along a climatic gradient. Environ. Entomol. 33: 45-53.

Errouissi F., Jay-Robert P., Lumaret J.P. \& Piau O. 2004b: Composition and structure of dung beetle (Coleoptera: Aphodiidae, Geotrupidae, Scarabaeidae) assemblages in mountain grasslands of the Southern Alps. Ann. Entomol. Soc. Am. 97: 701-709.

Fincher G.T., Monson W.G. \& Burton G.W. 1981: Effects of cattle faeces rapidly buried by dung beetles on yield and quality of coastal Bermuda grass. Agron. J. 73: 775-779.

FinN J.A. \& GitTingS T. 2003: A review of competition in north temperate dung beetle communities. Ecol. Entomol. 28: 1-13.

FinN J.A., GitTingS T. \& Giller P.S. 1999: Spatial and temporal variation in species composition of dung beetle assemblages in southern Ireland. Ecol. Entomol. 24: 24-36.

Galante E., Mena J. \& Lumbreras C. 1995: Dung beetles (Coleoptera: Scarabaeidae, Geotrupidae) attracted to fresh cattle dung in wooded and open pasture. Environ. Entomol. 24: $1063-1068$

Gitting T., Giller P.S. \& Stakelum G. 1994: Dung decomposition in contrasting temperature pastures in relation to dung beetle and earthworm activity. Pedobiologia 38: 455-474.

Haloti S., Janati-Idrissi A., Chergui H. \& Lumaret J.P. 2006: Structure des communautés de Scarabéidés coprophages du 
Maroc nord-occidental (Coleoptera, Scarabaeoidea). Bull. Inst. Sc. Rabat (Maroc) 28: 25-34.

HANSKI I. 1980: Spatial variation in the timing of the seasonal occurrence in coprophagous beetles. Oikos 34: 311-321.

HANSKI I. 1989: Dung beetles. In Leith H. \& Verger M.J.A. (eds): Tropical Rain Forest Ecosystems. Elsevier Science Publications, Amsterdam, pp. 489-511.

HansKi I. 1991: North temperate dung beetles. In Hanski I. \& Cambefort Y. (eds): Dung Beetle Ecology. Princeton University Press, Princeton, pp. 75-96.

Hanski I. \& Cambefort Y. 1991: Competition in dung beetles. In Hanski I. \& Cambefort Y. (eds): Dung Beetle Ecology. Princeton University Press, Princeton, NJ, $481 \mathrm{pp}$.

Holter P. 1982: Resource utilization and local coexistence in a guild of scarabaeid dung beetles (Aphodius spp.). Oikos 39: 213-227.

JANATI-IDRISSI A. 2000: Les Scarabéides Coprophages des Pelouses Sèches du Maroc Occidental: Structure des Communautés et Rôle Ecologique (Coleoptera: Scarabaeoidea). Thèse doct., Biologie des Populations et Ecologie, Univ. Sidi Mohamed ben Abdellah, Fès, Maroc.

JANATI I.A., KADIRI N. \& LumARET J.P. 1999: Le partage du temps et de l'espace entre les guildes de Coléoptères coprophages dans le Moyen-Atlas (Maroc). Ann. Soc. Entomol. Fr. (N.S) 35: 213-221.

JAY-RoBert P. 1997: Dynamique des Introgressions Réciproques de la Faune des Scarabéides Coprophages entre la Zone Méditerranéenne et la Chaîne Alpine. Implications Biogéographiques. Thèse doct., Biologie des Populations et Ecologie, Univ. Montpellier III, France.

Jay-Robert P., Errouissi F. \& Lumaret J.P. 2008a: Temporal coexistence of dung-dweller and soil-digger dung beetles (Coleoptera, Scarabaeoidea) in contrasting Mediterranean habitats. Bull. Entomol. Res. 98: 303-316.

Jay-Robert P., Lumaret J.P. \& Lebreton J.D. 2008b: Spatial and temporal variation of mountain dung beetle assemblages and their relationships with environmental factors (Aphodiidae, Geotrupidae, Scarabaeidae). Ann. Entomol. Soc. Am. 101: 58-69.

Krell F.T., Krell-Westerwalbesloh S., Weiss I., Eggleton P. \& Lisenmair K.E. 2003: Spatial separation of Afrotropical dung beetle guilds: a trade-off between competitive superiority and energetic constraints (Coleoptera: Scarabaeidae). Ecography 26: 210-222.

Krell-Westerwalbesloh S., Krell F.T. \& Lisenmair K.E. 2004: Diel separation of Afrotropical dung beetle guildsavoiding competition and neglecting resources (Coleoptera: Scarabaeoidea). J. Nat. Hist. 38: 2225-2249.

LANDIN B.O. 1961: Ecological studies on dung beetles (Col. Scarabaeidae). Opusc. Entomol. (Suppl.) 19: 1-227.

Lobo J.M., Martin-Piera F. \& Veiga C.M. 1988: Las trampas pitfall con cebo, sus posibilidades en el estudio de las communidades coprofagas de Scarabaeidae (Col.). I. Caracteristicas determinantes de su capacidad de captura. Rev. Ecol. Biol. Sol. 25: 77-100.

Lobo J.M., Lumaret J.P. \& Jay-Robert P. 1998: Sampling dung beetles in the French Mediterranean area: effects of abiotic factors and farm practices. Pedobiologia 42: 252-266.

Lobo J.M., Lumaret J.P. \& Jay-RoberT P. 2002: Modelling the species richness distribution of French dung beetles and delimiting the predictive capacity of different groups of explanatory variables (Coleoptera: Scarabaeidae). Global Ecol. Biogeogr. 11: 265-277.

Lobo J.M., Jay-Robert P. \& Lumaret J.P. 2004: Estimating the explanatory power of several variables and modelling the spe- cies richness distribution for French Aphodiidae (Coleoptera, Scarabaeoidea). Ecography 27: 145-156.

LUMARET J.P. 1995: Desiccation rate of excrements: a selective pressure on dung beetles. In Roy J., Aronson J. \& Di Castri F. (eds): Time Scales of Biological Responses to Water Constraints. The Case of Mediterranean Biota. SPB Academic Publishing, Amsterdam, pp. 105-118.

LuMARET J.P. \& KirK A.A. 1987: Ecology of dung beetles in the French Mediterranean region (Coleoptera: Scarabaeidae). Acta Zool. Mex. 24: 1-55.

Lumaret J.-P. \& Stiernet N. 1991: Montane dung beetles. In Hanski I. \& Cambefort Y. (eds): Dung Beetle Ecology. Princeton Univ. Press, Princeton, NJ, 481 pp.

Lumbreras Vicente C.J. 1998: Estudio de la Microsucesiones de Coleópteros Coprófagos en Encinares Adehesados y Evaluación de los Efectos Derivados del Uso de Fármacos Antiparasitarios (Coleoptera: Scarabaeoidea). Thèse doct., Univ. Alicante, Spain.

Martin-Piera F. 1992: Le projet "Fauna Ibérica". Mém. Soc. $R$. Belge Entomol. 35: 689-692.

MoHr C.O. 1943: Cattle droppings as ecological units. Ecol. Monogr. 13: 275-298.

Moreno C.E. \& Halffter G. 2001: Spatial and temporal analysis of $\alpha, \beta$ and $\gamma$ diversities of bait in fragmented landscape. Biodiv. Conserv. 10: 367-382.

Nabli M.A. 1995: Essai de Synthèse sur la Végétation et la Phyto-écologie Tunisiennes. II \& III. Le Milieu Physique et la Végétation. Écologie Végétale Appliquée. Université de Tunis, Tunisie, $542 \mathrm{pp}$.

Niogret J. 2007: Interactions Multipolaires entre Coléoptères, Acariens et Diptères. Stratégies de Dispersion pour l'Utilisation de Ressources Trophiques Ephémères. Thèse doct., Biologie des Populations et Ecologie, Univ. Montpellier III, France.

Rougon C. \& Rougon D. 1980: Le cleptoparasitisme en zone sahélienne: phénomène adaptatif d'insectes Coléoptères Scarabaeidae aux climats arides et semi-arides. C. R. Acad. Sci. Paris (D) 291: 417-419.

Rougon D. \& Rougon C. 1983: Nidification des Scarabaeidae et cleptoparasitisme des Aphodiidae en zone sahélienne (Niger) et leur rôle dans la fertilisation des sols sableux. Bull. Soc. Entomol. Fr. 88: 496-513.

Sanchez-Pinero F. \& Avila J.M. 2004: Dung-insect community composition in arid zone of south-eastern Spain. J. Arid Environ. 56: 303-327.

SowIG P. 1997: Niche separation in coprophagous beetles: a comparison of two multivariate approaches. Bull. Entomol. Res. 87: 625-631.

Veiga C.M., Lobo J.M. \& Martin-Piera F. 1989: Las trampas pitfall con cebo, sus posibilidades en el estudio de las communidades coprofagas de Scarabaeidae (Col.). II. Analisis de efectividad. Rev. Ecol. Biol. Sol 26: 91-109.

WASSMER T. 1994: Seasonality of coprophagous beetles in the Kaiserstuhl area near Freiburg (SW-Germany) including the winter months. Acta Oecol. 15: 607-631.

Wolda H. 1988: Insect seasonality. Annu. Rev. Ecol. Syst. 19: $1-18$.

YASUDA H. 1984: Seasonal changes in the numbers and species of Scarabaeid dung beetles in the middle part of Japan. $J$. App. Entomol. Zool. 28: 217-222.

Zamora J., Verdu J.R. \& Galante E. 2007: Species richness in Mediterranean agroecosystems: Spatial and temporal analysis for biodiversity conservation. Biol. Conserv. 134: 113-121.

Received June 4, 2008; revised and accepted October 6, 2008 